\title{
https://doi.org/10.1038/s41467-020-17748-7
}

\section{Author Correction: Jawsamycin exhibits in vivo antifungal properties by inhibiting Spt14/Gpi3-mediated biosynthesis of glycosylphosphatidylinositol}

Yue Fu (D), David Estoppey (D), Silvio Roggo, Dominik Pistorius, Florian Fuchs D, Christian Studer, Ashraf S. Ibrahim, Thomas Aust, Frederic Grandjean (D), Manuel Mihalic, Klaus Memmert, Vivian Prindle (D), Etienne Richard, Ralph Riedl, Sven Schuierer (D), Eric Weber, Jürg Hunziker, Frank Petersen, Jianshi Tao (i) \& Dominic Hoepfner (D)

Correction to: Nature Communications https://doi.org/10.1038/s41467-020-17221-5, published online 7 July 2020.

The original version of this Article omitted the following from the Acknowledgements:

We also thank the Novartis Chemical \& Pharmaceutical Profiling \& DMPK teams for their support on evaluation of in vivo efficacy of Jawsmycin.

This has now been corrected in both the PDF and HTML versions of the Article.

Published online: 31 July 2020

\footnotetext{
(c) Open Access This article is licensed under a Creative Commons Attribution 4.0 International License, which permits use, sharing, adaptation, distribution and reproduction in any medium or format, as long as you give appropriate credit to the original author(s) and the source, provide a link to the Creative Commons license, and indicate if changes were made. The images or other third party material in this article are included in the article's Creative Commons license, unless indicated otherwise in a credit line to the material. If material is not included in the article's Creative Commons license and your intended use is not permitted by statutory regulation or exceeds the permitted use, you will need to obtain permission directly from the copyright holder. To view a copy of this license, visit http://creativecommons.org/licenses/by/4.0/.
}

(C) The Author(s) 2020 